\title{
THE INTENSIFICATION OF FOREIGN TRADE IN POST-SOCIALIST COUNTRIES AND THEIR ROLE IN GLOBAL VALUE CHAINS
}

\author{
Ewa CIEŚLIK - Jadwiga BIEGAŃSKA - Stefania ŚRODA-MURAWSKA
}

(Received: 4 June 2015; revision received: 15 August 2015; accepted: 15 October 2015)

\begin{abstract}
This article presents the transformation of foreign trade in 10 post-socialist countries, current members of the EU. Special focus is given to the more significant role these countries began to play in global value chains (GVCs) as a result of liberalisation processes and integration within the EU. In addition, the article evaluates their place in global vertical specialisation. To locate each country on a global value chain and to compare them with selected countries, more complex methods of measuring the level of participation of European post-socialist countries in GVCs were employed. These methods allow the position of a country downstream or upstream in GVCs to be established. We concluded that (a) post-socialist countries differ in the levels of their participation in GVCs. Countries that have stronger links with Western European countries, especially with Germany, are more integrated; (b) a large share of post-socialist countries' exports pass through Western European GVCs; (c) most exporters in Central and Eastern Europe are positioned in downstream segments of production rather than upstream markets.
\end{abstract}

Keywords: Central and Eastern Europe, foreign trade, global value chains

JEL classification indices: F14, F15, O52

Ewa Cieślik, corresponding author. Assistant Professor at the Faculty of International Business and Economics, Poznan University of Economics and Business, Poland. E-mail: ewa.cieslik@ ue.poznan.pl

Jadwiga Biegańska, Assistant Professor at the Department of Urban Studies and Regional Development, Nicolaus Copernicus University in Toruń, Poland. E-mail: jadwigab@umk.pl

Stefania Środa-Murawska, Assistant Professor at the Department of Urban Studies and Regional Development, Nicolaus Copernicus University in Toruń, Poland. E-mail: steffi@umk.pl 


\section{INTRODUCTION}

The collapse of the communist system and the disintegration of the USSR were followed by transitional recession in the post-socialist countries of Europe. Its main sources lay in wide-ranging reforms to the economic system such as the transition from a producers' market toward a consumers' market, the transformation of the structure of post-socialist economies, the modernisation of their obsolete financial systems, the imposition of financial discipline, and attempts at improving general economic efficiency (Kornai 1994). Aimed at fixing flaws inherited from the past, the reforms placed post-socialist countries in a new geopolitical and international context, particularly regarding trade and capital relations. At the same time, the development goals pursued from the 1990s were becoming increasingly similar. Democratisation, integration with the European Union (EU), the strengthening of bilateral and multilateral political and economic relations, and the modernisation of financial sectors, particularly of banking systems (Baszyński 2013), were common elements of their long-term development strategies. The methods and tools they used to attain their goals were different though (Ananicz - Sadowski 2012).

One of the key changes in the economic policy of post-socialist countries was the redirection of their foreign trade towards Western Europe and the introduction of market mechanisms into their international trade (Środa-Murawska 2007; Maćkowiak 2011). The liberalisation of foreign trade in Central and Eastern Europe (CEE) quickly led to the formation of new trade rules in the region (Cieślik 2014a).

In countries other than the most developed, the liberalisation of foreign trade did not necessarily contribute to faster social and economic development (Rynarzewski 2013), but in the case of post-socialist countries it did. An analysis of trends in the geographical and commodity patterns of foreign trade in European post-socialist countries shows major changes. More and more often, exports of labour- and raw material-intensive products are replaced by capital-intensive and high-tech ones. As a result, the foreign trade patterns observed in post-socialist countries are increasingly similar to those in the EU-15. The growing integration between post-socialist countries and the EU makes the CEE region increasingly attractive to foreign investors. Their investments significantly contribute to the competitiveness of trade, as well as accounting for a large proportion of their foreign trade.

The aim of this article is to analyse changes in the commodities foreign trade in the new member states (EU-10), i.e. Bulgaria, the Czech Republic, Estonia, Hungary, Latvia, Lithuania, Poland, Romania, Slovakia, and Slovenia, and the role these states play in global value chains as a result of liberalisation and integration 
with the EU. The analysis spans the years 2000-2009. To ensure consistency and comparability of results, the data sources were databases kept by international organisations (OECD, and WTO).

\section{EUROPEAN POST-SOCIALIST COUNTRIES AND THEIR ROLE IN GLOBAL PRODUCTION NETWORKS: A BRIEF LITERATURE REVIEW}

The post-socialist countries are heavily involved in the process of global production, especially within Europe. Smaller countries like all CEE nations are not able to produce all the inputs themselves and thus tend to be more vertically integrated (Stehrer et al. 2012). A growing strand of recent research is devoted to analyses of the fragmentation of production and its impact on post-socialist countries and their industries. Much empirical research demonstrates the close and dynamic integration of the CEE region with the EU market (especially the euro area). Research by the IMF (2011) proved this thesis and highlighted that exporters from European post-socialist countries involved in value networks were often owned outright by EU companies or operated as joint ventures of euro area companies. Dobrinsky (1995) highlighted the fact that post-socialist countries were more specialised in the labour-intensive and resource-intensive sectors of manufacturing by using their comparative advantages. Moreover, specialisation is the effect of higher foreign direct investment (FDI) inflows and trade in the sector (intra-industry trade). Behar - Freund (2011) examined how fragmentation of production in Europe has changed and developed, and discussed how integration has facilitated the volume and increasing complexity of intra-EU trade in intermediate products. Amador et al. (2013) and Altomonte et al. (2012) also proved that CEE nations are an important part of the trade in intermediate goods. However, there has been a slight drop in this trade. Marin (2006) examined German and Austrian investments in CEE countries to present a pattern of intra-company trade and the emergence of selected Eastern European nations in the international fragmentation of production.

More detailed surveys that focus on selected sectors of CEE economies can be found. Kaminski - Ng $(2001,2005)$ investigated the trade networks. They emphasised that the growth of specialisation in manufacturing was an important driver of the economic growth of many transitional CEE states. They showed that these production linkages underwent significant transition: a shift from labourintensive simple assembly operations to processing and local production of parts, and an expansion beyond EU markets. Moreover, they presented the integration of CEE countries into EU production networks in three sectors especially: furniture (which is characteristic of almost all economies analysed), automotives (the 
Czech Republic, Hungary, Poland, Slovakia, and Slovenia), and sectors experiencing the "information revolution" (Estonia and Hungary). Similar results were presented by Timmer et al. (2012). They analysed nations specialising mainly in electronics (Hungary, Slovakia), machinery (Czech Republic, Slovakia), and transport equipment (all states), and demonstrated that the CEE region increased its proportion of income from participation in global value chains in Europe from $4.4 \%$ in 1995 to $9.3 \%$ in 2008 , with a continuous growth in the number of highskilled workers involved in production processes. The same tendency was shown by Pavlinek (2005) and Jürgens - Krzywdzinski (2009). They indicated that the CEE region is a production hub for European automotive producers with global suppliers, near enough to Western Europe to supply parts on a just-in-time basis. Similar results were found in Backer's and Miroudot's survey (2013). In turn, Simkova (2013) pointed out the sectors in CEE states which were on the whole integrated into Global Value Chains (GVCs). In addition to the automotive industry (almost all analysed nations), there was electrical engineering (Poland, Slovakia) and mechanical engineering (Poland, Czech Republic, and Bulgaria). Labrianidis et al. (2008) examined the electronics sector and showed that in Europe, the past two decades have seen a deepening of integration that has been paralleled by shifting production capacity from Western Europe to post-socialist states. De Simone (2008), in turn, used trade in parts and components as an independent variable to determine changes in the industrial geography of the EU-15 and CEE states. According to his results, the contribution of imported intermediates is positive and substantial in the "automotive sector and office machinery" industries. In these two sectors, higher levels of imports of intermediate products go with a higher relative proportion of sectoral production. Akbar - Ferencikova (2007) also discovered from their questionnaire-based research that most suppliers in the automotive sector in Slovakia were second-tier, producing mainly standardised parts for global first-tier suppliers. Sass - Szalavetz (2013) in turn analysed the effects of the crisis on GVC for integrated Hungarian automotive and electronic industries. According to their results, companies have had functional upgrading effects caused by the global crisis and the reorganisation of corporations. More detailed case studies have presented an ongoing industrial upgrading in the CEE region generally. Whereas early participation in a GVC concentrated mainly on assembly operations, tasks of higher complexity are increasingly being performed and the new EU members have become important suppliers of products and parts.

The global crisis induced certain positive effects on GVCs in CEE countries. Recently, however, some surveys have shown that because most strategic decisions regarding industrial location are being made in Western Europe, further upgrading in GVCs might be very difficult to achieve (Jacoby 2010; Fortwengel 2011). According to Stehrer et al. (2012b), Central, Eastern and Southeastern EU 
members appear to be the most interlinked, exhibiting strong bilateral linkages with EU-15 members.

In sum, according to numerous surveys, CEE states are found lower down the value chain networks. Nevertheless, they do not have an obvious specialisation in regard to labour-intensive or low-skill undertakings. CEE countries are found in relatively downstream activities of global production chains; acquired technology, capital, and know-how have underpinned the expansion and competitiveness of their exports. Climbing the GVC into knowledge-intensive production is a prime concern. Nevertheless, we should be aware that post-socialist states face strong competition from Asian countries, especially from China, that are determined to rise up the manufacturing value chain and are developing capabilities in knowledge-intensive manufacturing (Cieślik 2014b, 2015).

\section{METHODOLOGY}

With contemporary international production chains, value added (VA) has its origins in many locations. Specifying these sources and trying to measure their contribution to exports is crucial for a number of research and policy questions, but the existing measures are mostly unsatisfactory. The "HIY" method, proposed by Hummels et al. (2001), provided the first empirical measure of participation in vertically specialised trade. ${ }^{1}$

If we want to reflect foreign content in exports, the HIY measure requires two main assumptions: (a) first, all imported intermediate inputs must contain 100\% foreign VA and no more than one country can export intermediates; (b) second, intensity in the use of imported inputs is assumed to be the same, irrespective of whether goods are produced for export or for domestic consumption.

We assume that we have a two-country (one home, one foreign) world, in which each country produces goods in N-differentiated tradable sectors. Goods in each sector can be consumed directly or used as intermediate inputs. Moreover, each country exports both intermediate and final goods to the other.

The entire gross output produced by country $r$ must be used as an intermediate good or a final good at home or abroad, or

$$
X_{r}=A_{r r} X_{r}+A_{r s} X_{s}+Y_{r r}+Y_{r s}, \quad r, s=1,2
$$

However, their measure of foreign value in exports is valid only in a special case; they did not mathematically define their measure of indirect value-added exports through third countries; and these two measures do not capture all sources of VA in gross exports (Koopman et al. 2010). 
where $X_{r}$ is the $\mathrm{N} \times 1$ gross output vector of a country $r$; $Y_{r s}$ is the $\mathrm{N} \times 1$ final demand vector that gives demand in country $s$ for final goods produced in $r ; A_{r} s$ is the $\mathrm{N} \times \mathrm{N}$ IO coefficient matrix, giving intermediate use in $s$ of goods produced in $r$.

The two-country production and trade system can be written as an ICIO model in block matrix notation as follows:

$$
\left[\begin{array}{l}
X_{1} \\
X_{2}
\end{array}\right]=\left[\begin{array}{l}
A_{11} A_{12} \\
A_{21} A_{22}
\end{array}\right]\left[\begin{array}{l}
X_{1} \\
X_{2}
\end{array}\right]+\left[\begin{array}{l}
Y_{11}+Y_{12} \\
Y_{21}+Y_{22}
\end{array}\right]
$$

and rearranged,

$$
\left[\begin{array}{l}
X_{1} \\
X_{2}
\end{array}\right]=\left[\begin{array}{l}
I-A_{11}-A_{12} \\
-A_{21} I-A_{22}
\end{array}\right]^{-1}\left[\begin{array}{l}
Y_{11}+Y_{12} \\
Y_{21}+Y_{22}
\end{array}\right]=\left[\begin{array}{l}
B_{11}+B_{12} \\
B_{21}+B_{22}
\end{array}\right]\left[\begin{array}{l}
Y_{1} \\
Y_{2}
\end{array}\right]
$$

where $B_{s r}$ denotes the $\mathrm{N} \times \mathrm{N}$ block Leontief inverse matrix, which is the total requirement matrix that gives the amount of gross output in producing country $s$ required for a one-unit increase in final demand in country $\mathrm{r}$.

$Y_{r}$ is a $2 \mathrm{~N} \times 1$ vector that gives the global use of $r$ 's final goods.

This can be expressed succinctly as:

$$
X=(I-A)^{-1} Y=B Y
$$

where $X$ and $Y$ are $2 \mathrm{~N} \times 1$ vectors, and $A$ and $B$ are $2 \mathrm{~N} \times 2 \mathrm{~N}$ matrices.

Having defined the Leontief inverse matrix, we turn to measures of domestic and foreign content (first for production, and then applied to trade).

We agree that:

$V_{s}$ will be the $1 \times \mathrm{N}$ direct VA coefficient vector and each element of $V_{s}$ gives the share of direct domestic VA in total output. This amounts to one minus the intermediate input share from all countries:

$$
V_{r} \equiv u\left(I-\sum_{s} A_{s r}\right)
$$

where $u$ is a $1 \times \mathrm{N}$ unity vector. To be consistent with the "multiple-country" discussion below, we should also define $V$, the $2 \times 2 \mathrm{~N}$ matrix of direct domestic VA for both countries,

$$
V=\left[\begin{array}{cc}
V_{1} & 0 \\
0 & V_{2}
\end{array}\right]
$$

Combining these direct VA shares with the Leontief inverse matrices produces the $2 \times 2 \mathrm{~N}$ VA share (VAS) matrix, our main measure of VA shares by source. 


$$
V A S=V B\left[\begin{array}{ll}
V_{1} B_{11} & V_{1} B_{12} \\
V_{2} B_{21} & V_{2} B_{12}
\end{array}\right]
$$

Within VAS, each column of $V_{l} B_{l l}$ denotes domestic VA share of domestically produced products in a particular sector at home. Similarly, the columns of $V_{2} B_{21}$ denote the share of "country 2's" VA in these same goods. Each of the first N columns in the VAS matrix includes all VA, domestic and foreign, required to produce one additional unit of domestic product at home. The second $\mathrm{N}$ columns present VA shares for production in "country 2". All VA must be either domestic or foreign, hence the sum down each column is unity:

$$
V_{1} B_{11}+V_{2} B_{21}=V_{1} B_{12}+V_{2} B_{22}=u .
$$

The VAS matrix contains all the necessary information to separate domestic and imported content in the production and trade of a particular country at a sectoral level. Either exports of final goods or total gross exports could be used as "weights" to assess these proportions when aggregation is necessary. In order to compare other measures of vertical specialisation, and to link our measures with official trade statistics, we use gross exports. Let $E_{r s}$ be the $\mathrm{N} \times 1$ vector of gross exports from $r$ to $s$. For consistency with the "multiple country" analysis below, we will define

$$
\begin{gathered}
E_{r^{*}}=\sum_{s \neq r} E_{r s}=\sum_{s}\left(A_{r s} X_{s}+Y_{r s}\right), \quad r, s=1,2 \\
E=\left[\begin{array}{cc}
E_{1} & 0 \\
0 & E_{2}
\end{array}\right]
\end{gathered}
$$

and

$$
\hat{E}=\left[\begin{array}{cc}
{\left[(\operatorname{diag}(E)]_{1^{*}}\right.} & 0 \\
0 & {\left[(\operatorname{diag}(E)]_{2^{*}}\right.}
\end{array}\right]
$$

where $E$ is a $2 \mathrm{~N} \times 2$ matrix and $\hat{E}$ is a $2 \mathrm{~N} \times 2 \mathrm{~N}$ diagonal matrix.

The combination of the VA share matrix and an export matrix as weights produces a $2 \times 2 \mathrm{~N}$ matrix VAS_ $\hat{E}$, our sectoral measure of VA share by source country:

$$
\mathrm{VAS} \_\hat{\mathrm{E}} \equiv V B \hat{\mathrm{E}}\left[\begin{array}{lll}
V_{1} B_{11} \hat{E}_{1} & V_{1} B_{12} \hat{E}_{1} \\
V_{2} B_{21} & \hat{E}_{1} & V_{2} B \hat{E}_{2}
\end{array}\right] \text {. }
$$


The elements of this matrix provide disaggregated VA by source in gross exports for each sector. It is important to add that this measure captures all upstream sector contributions to VA within a specific sector's gross exports.

Domestic/foreign content of exports and VA exports, if we consider them as related, are different concepts. However, both concepts measure the value generated by factors used in the producing country, domestic content of exports is independent of where that value is employed. By contrast, VA trade depends on how a country's exports are used by importers. It is VA produced by one country, but absorbed by another. Therefore, equation (12) shows related measures of domestic/foreign content in sector level gross exports, not sector level VA exports. Because the later matrix (after zeroing its diagonal):

$$
\mathrm{VA} \mathrm{T} \equiv \hat{V} B Y=\left[\begin{array}{ll}
\hat{V}_{1} & O \\
O & \hat{V}_{2}
\end{array}\right]\left[\begin{array}{ll}
B_{11} & B_{12} \\
B_{21} & B_{22}
\end{array}\right]\left[\begin{array}{ll}
Y_{11} & Y_{12} \\
Y_{21} & Y_{22}
\end{array}\right]
$$

depends on where the VA is absorbed, it has to be defined in the context of final demand, where $Y_{s r}$ is an $\mathrm{N}$ by 1 vector; $Y$ is $2 \mathrm{~N}$ by 2 final demand matrix; $\hat{V}_{r}$ is a $\mathrm{N}$ by $\mathrm{N}$ diagonal matrix with direct VA coefficients along the diagonal and has different dimension with $V$ matrix defined earlier.

The resulting VÂT is a $2 \mathrm{~N}$ by 2 VA production matrix, its diagonal elements give each country's production of VA absorbed by itself, while its off-diagonal elements constitute the $2 \mathrm{~N}$ by 2 bilateral VA trade matrix. The VA trade matrix is the off-diagonal element of VÂT, therefore, it excludes VA produced in the home country that returns home after processing abroad.

To illustrate these two major concepts and their relations in the simplest possible way, we will aggregate the version throughout the rest of this section. The aggregate $(2 \times 2)$ measure of VA by source in gross exports is given by

$$
\text { VAS_E } \equiv V B E\left[\begin{array}{lll}
V_{1} B_{11} E_{1^{*}} & V_{1} B_{12} E_{2} \\
V_{2} B_{21} E_{1^{*}} & V_{2} B E_{2^{*}}
\end{array}\right] .
$$

Although rather elementary with only two countries, VAS_E shows the major concepts of new VA by source measure. Additionally, diagonal elements of VAS_E define the domestic VA in each country's exports and off-diagonal elements give the foreign VA embodied in each country's exports.

In the two-country case, explicit solutions for the four $B_{r s}$ block matrices are not too difficult, and enable us to demonstrate why HIY's vertical specialisation measures are a special case of new general measures. Applying the algebra of the partitioned matrix inverse, we have 


$$
\left[\begin{array}{ll}
B_{11} & B_{12} \\
B_{21} & B_{22}
\end{array}\right]=\left[\begin{array}{cc}
\left(I-A_{11}-A_{12}\left(I-A_{22}\right)^{-1} A_{21}\right)^{-1} & B_{11} A_{12}\left(I-A_{22}\right)^{-1} \\
\left(I_{2}-A_{22}\right)^{-1} A_{21} B_{11} & \left(I-A_{22}-A_{21}\left(I-A_{11}\right)^{-1} A_{12}\right)^{-1}
\end{array}\right] \cdot(15
$$

Therefore, gross exports can be decomposed into foreign VA (or VS, following the HIY notation) and domestic VA (DV) in the following way:

$$
\begin{gathered}
D V=\left[\begin{array}{l}
V_{1} B_{11} E_{1^{*}} \\
V_{2} B_{22} E_{2^{*}}
\end{array}\right]=\left[\begin{array}{l}
V_{1}\left(I-A_{11}-A_{12}\left(I-A_{22}\right)^{-1} A_{21}\right)^{-1} E_{1^{*}} \\
V_{2}\left(I-A_{22}-A_{21}\left(I-A_{11}\right)^{-1} A_{12}\right)^{-1} E_{2^{*}}
\end{array}\right] \\
F V=\left[\begin{array}{l}
V_{2} B_{21} E_{1^{*}} \\
V_{1} B_{12} E_{2^{*}}
\end{array}\right]=\left[\begin{array}{l}
u\left(A_{21}-A_{12}\left(I-A_{22}\right)^{-1} A_{21}\right)\left(I-A_{11}-A_{12}\left(I-A_{22}\right)^{-1} A_{21}\right)^{-1} E_{1^{*}} \\
u\left(A_{12}-A_{21}\left(I-A_{11}\right)^{-1} A_{12}\right)\left(I-A_{22}-A_{21}\left(I-A_{11}\right)^{-1} A_{12}\right)^{-1} E_{2^{*}}
\end{array}\right] .
\end{gathered}
$$

They are both $2 \times 1$ matrices.

Using the same notation, the HIY measure of foreign VA can be shown as another $2 \times 1$ matrix:

$$
V S=\left[\begin{array}{l}
u A_{21}\left(I-A_{11}\right)^{-1} E_{1^{*}} \\
u A_{12}\left(I-A_{22}\right)^{-1} E_{2^{*}}
\end{array}\right]
$$

Comparing equations (17) and (18), we can note that the HIY measure only captures foreign VA in gross exports when either $\mathrm{A}_{12}=0$ or $\mathrm{A}_{21}=0$, i.e. in the case when only one country's intermediate goods are used abroad. The new measure captures an important element omitted from HIY's formula. For the home country, both domestic and foreign VA varies from its true value by $A_{12}\left(I-A_{22}\right)^{-1} A_{21} E_{21}$. Thus the new measure can account for a country importing its own VA which has been exported but returns home after being processed abroad. In a general context, VAS_E will attribute foreign and domestic content to multiple countries in an appropriate way when intermediate products cross borders in even more complicated patterns.

The second HIY measure of vertical specialisation (labelled as VS1 by HIY) details domestic VA in inputs exported indirectly to third countries. In a twocountry world, the home country's IV (indirectly exported VA) is identical to the foreign country's FV:

$$
\mathrm{IV}_{1}=V_{1} B_{12} E_{21} \text {. }
$$

By using the decomposition results at a country-sector level, we can construct an index that helps us to assess if a country is likely to be upstream or down- 
stream in the GVC in any sector. We can also construct a separate index that helps us to assess the extent to which such a country-sector is involved in the global production chain.

For an index to capture a country's position (i.e. upstream or downstream), it is possible to compare that country's exports of intermediates in that sector that are used by other countries, with that country's use of imported intermediates in the same sector. If a country lies upstream in the GVC, it produces inputs for others, either by providing raw materials (such as Russia), or by providing manufactured intermediates (such as Japan), or both. For such a country, its indirect VA (IV) share in gross exports will be higher than its FV share. Comparing this with a country which lies downstream in a GVC, we can observe that it will use a large portion of other countries' intermediates to produce final goods for export, and its FV share will be higher than its IV share.

We define a "country-sector" index for the position in a GVC as the log ratio of a country-sector's supply of intermediates used in other countries' exports to the use of imported intermediates in its own production.

$$
\text { GVC_Position }_{i r}=\operatorname{Ln}\left(1+\frac{I V_{i r}}{E_{i r}}\right)-\operatorname{Ln}\left(1+\frac{F V_{i r}}{E_{i r}}\right)
$$

If the country-sector lies upstream in a supply chain, the numerator tends to be large. On the other hand, if it lies downstream, then the denominator tends to be large.

Of course, two countries can have the same GVC position index in one sector while having very different levels of participation in GVCs. Therefore, the position index must be used in conjunction with another index that summarises the significance of the global supply chain for that country-sector. Finally, we define a GVC participation index as

$$
G V C_{-} \text {Participation }_{i r}=\frac{I V_{i r}}{E_{i r}}+\frac{F V_{i r}}{E_{i r}} .
$$

If a country is located in the upstream segment in a production value chain (first stages of production), it is likely that it has a high level of forward participation relative to backward. This means that the country relies more on its own production. If a country specialises in the final stages of production (downstream segment), it is likely that it imports a lot of intermediate goods from abroad and therefore it has high level of backward participation. The GVC position index is constructed in such a way that states with high forward relative to backward participation have a value above zero. A more general approach indicates that upstream economies produce the raw materials or knowledge assets at the begin- 
ning of the production process (e.g. R\&D or design tend to create more VA than assembly does), while downstream economies assemble processed products or specialise in customer services.

\section{THE ROLE OF POST-SOCIALIST COUNTRIES IN GLOBAL VALUE CHAINS}

Because of the transition processes and growing integration between post-socialist economies and EU markets, CEE countries entered GVCs (Dicken et al. 2011). The liberalisation of trade and investment linkages between the EU-15 and the new member states, as well as their role in GVCs, had a major effect on the shape of international economic relations in the region. The commodity and geographical patterns of foreign trade in post-socialist countries was transformed by production delocation and fragmentation processes occurring in the last years of the sample period.

Development of CEE countries encouraged EU-based firms to shift their production to post-socialist states in order reduce their production costs, particularly the cost of labour, and to exploit the comparative advantages of CEE countries (efficiency-seeking investments). The compensation for the considerably lower productivity of labour in post-socialist countries compared with the EU-152 was to be hourly pay below the euro zone average. ${ }^{3}$ Because of lower costs, a relatively good infrastructure, and progressing liberalisation and integration with the $\mathrm{EU}$, post-socialist countries received massive inflows of investments onto greenfield sites from Western Europe. Following the relocation of production, new factories were constructed. ${ }^{4}$ Asian and US firms found that post-socialist countries as a gateway to more developed markets in the EU made investments as well (Cieślik 2012). ${ }^{5}$ For many investors, the markets of the new member countries in themselves were sufficient and very attractive locations for their FDI. The prior-

2 For instance, in 2005, labour productivity in Poland was $56 \%$ of that in the EU-15; in the Czech Republic it was $66 \%$, in Hungary $61 \%$, but in Bulgaria only $32 \%$. By 2012 , the rates had slightly increased to $67 \%$ in Poland and to $67 \%, 65 \%$, and $43 \%$ in the Czech Republic, Hungary, and Bulgaria, respectively (Eurostat 2014).

3 In 2012, the average hourly pay in the EU-15 was $€ 38.6$; in Poland it was $€ 10.4$, in the Czech Republic $€ 13.3$, in Hungary $€ 11.4$, and in Bulgaria $€ 5$. The highest average rate was paid in Slovenia: $€ 20.1$ (Eurostat 2014).

4 The first post-socialist economy that admitted foreign capital for privatisation was Hungary.

5 Non-European corporations had different goals than those in the EU, though. The main reason for their investments in post-socialist countries was not the wish to gain access to local markets, but to avoid customs restrictions and to have easier access to the European Single Market (Ambroziak 2013). 
ity targets for foreign investors were Poland, the Czech Republic, and Hungary. ${ }^{6}$ Foreign investments ultimately caused the internationalisation of production in post-socialist countries, incorporated them into GVCs, and led to a new division of labour in Europe (Błasiak 2013).

The international fragmentation of production gave a boost to industries in post-socialist economies that had comparative advantages (Feenstra 1998). Increased internationalisation and fragmentation of production might imply that an economy which uses potential comparative advantages, due to sourcing from other countries, having a comparative advantage in other stages of production or producing intermediate goods more cheaply than domestically might gain in competitiveness in some sectors, leading to better growth performance in terms of output or VA. Whether this is also the case for employment is a trickier question, as offshoring often has a similar effect on labour-saving technical progress, though the overall increase in output might compensate for that (Foster et al. 2013). Even though the speed of joining globalisation was quite high, international competitiveness remained relatively low. The most successful was Estonia, which in 2012 was ranked $34^{\text {th }}$ in the World Economic Forum ranking of 144 countries. Poland and the Czech Republic were respectively $41^{\text {st }}$ and $42^{\text {nd }}$ (World Economic Forum 2013).

In attempting to determine a country's position within GVCs, serious methodological problems and challenges must be overcome. This is partly caused by the non-existence of a standard method for measuring VA and by the lack of availability of relatively new data on VA flows in international trade. Therefore, to find out where post-socialist countries are on the value chain map, it is necessary to analyse VA in their trade. The first indication that a country may be entering a GVC is a decreasing share of domestic VA in its gross exports, implying a larger proportion of foreign VA and stronger linkages within GVCs. The countries analysed showed different trends in this respect. Generally, because of the proportion of domestic VA in gross exports, all of them were below the EU average. This proportion slightly decreased between 2000 and 2012 in four countries only (Czech Republic, Poland, Latvia, and Lithuania), thus indicating an expanding share of foreign VA (Graph 1). The case of the Hungarian and Czech automotive industries shows, however, that this simplified analysis does not allow a country's position in a GVC to be established. According to FDI flows, the automotive industry was the main beneficiary of foreign funds in both countries in the last years of the sample period, which proves its strong internationalisation

6 At the end of 2012, Poland accounted for over $29 \%$ of accumulated foreign direct investment in post-socialist countries, the Czech Republic for almost $16 \%$, Hungary for over $14 \%$, and Romania for more than 11\% (UNCTAD 2013). 


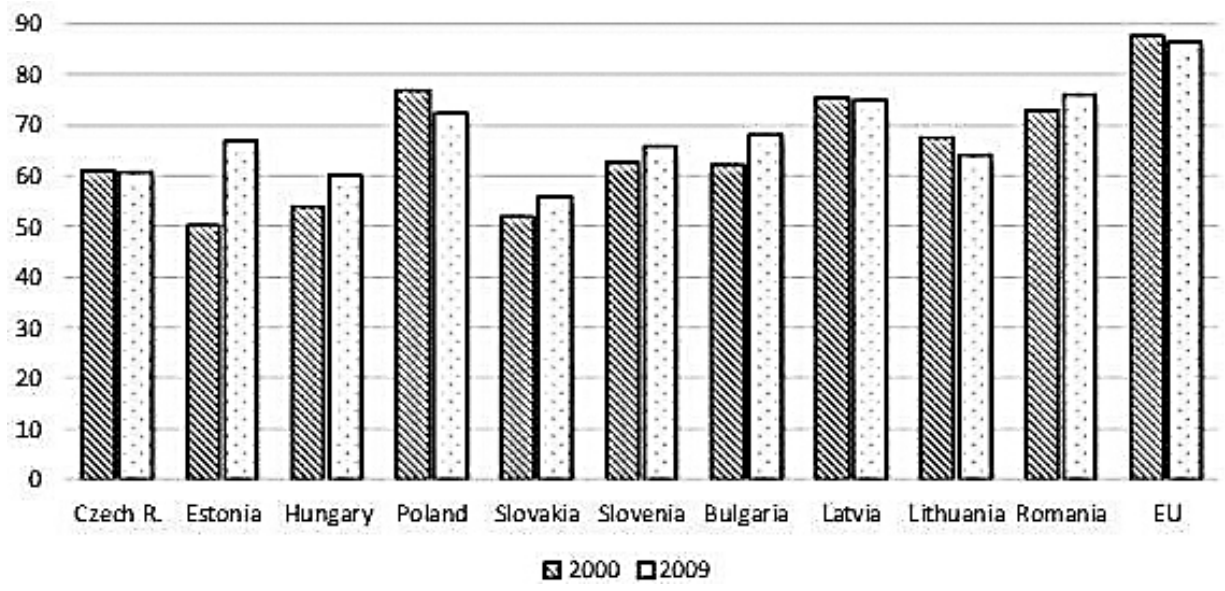

Graph 1. Domestic VA as a proportion of gross exports in post-socialist countries and the EU $(2000,2009, \%)$

Source: Based on TiVA OECD-WTO data (https://stats.oecd.org).

and integration with global production. This explicit conclusion cannot be drawn from the analysis of the share of domestic VA, which increased between 2000 and 2009 in both Hungary and the Czech Republic (OECD 2014).

Foreign VA as a part of the exports of post-socialist countries mostly comes from the EU-15. In other words, a large proportion of exports are integrated within EU value chains. This relationship is particularly clear in Slovakia, Hungary, and the Czech Republic, where over $40 \%$ of foreign VA in exports originates from the EU-15. In the Baltic States, particularly in Lithuania, linkages with EU value chains are much weaker than with value chains in Russia and Asia (OECD 2014).

An important indicator of a country's position in a GVC is the share of intermediate imports that are directly or indirectly used to export goods and services. In the exports of post-socialist countries, the proportion of intermediate imports is much greater than in the US or Japan. In 2009, it was highest in Slovakia (almost 70\%; the Polish rate was below 45\%). The intermediate import proportion of goods and services exports slightly increased in the analysed countries between 2000 and 2009, implying a slight decline in the production of high-tech products (Feenstra - Hanson 1999) (Graph 2).

Because of foreign investors' preference for automotive industries in postsocialist countries (the electronics sector was also frequently targeted in the later years of the sample), an analysis of the share of foreign VA in these sectors may 


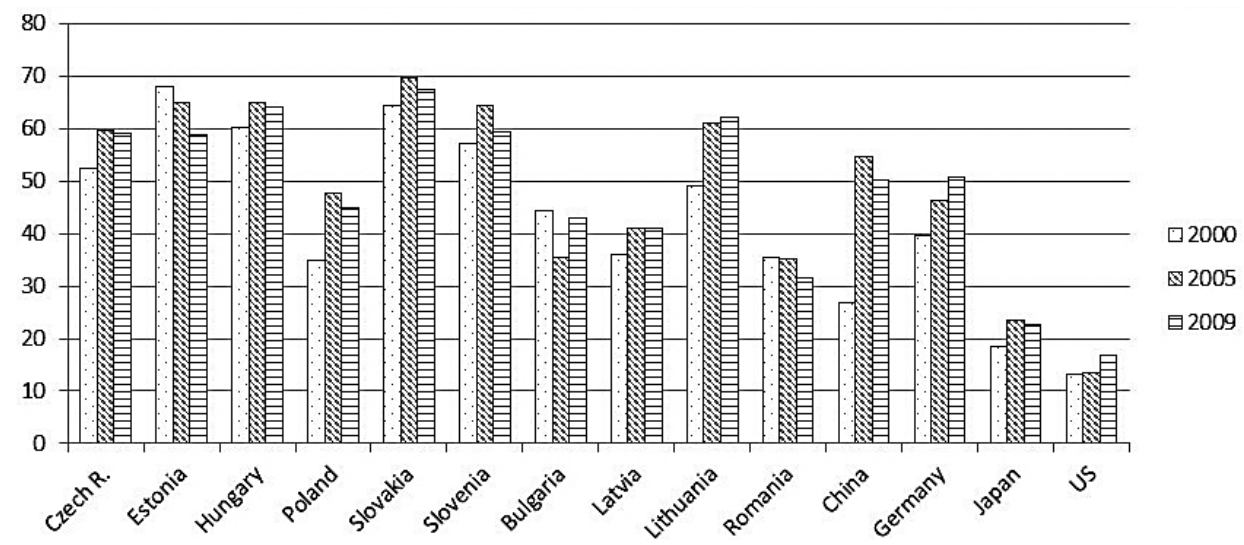

Graph 2. Intermediate imports as a proportion of goods and services exports in selected countries $(2000,2005,2009)$

Source: Based on TiVA OECD-WTO data (https://stats.oecd.org).

provide interesting information (Table 1). In the Slovakian, Hungarian, and Czech transport equipment sectors, particularly in the automotive industries, the proportion is high because large automotive companies have their factories there (Mihályi 2001). All three have considerable proportions of foreign VA in electronics exports, as well as higher indices for the number of international production stages for both industries (significantly exceeding the EU average). This points to the strong internationalisation of these industries and their reliance on foreign inputs, which translates into strong linkages with global value chains (Graph 3, Table 2).

Table 1. Inward FDI stocks in the electronics and transport equipment sectors in selected post-socialist countries $(2011, \%)$

\begin{tabular}{l|c|c}
\hline & Electronics & Transport equipment \\
\hline Slovakia & 4.2 & 17.3 \\
\hline Hungary & 17.1 & $19.5^{*}$ \\
\hline Czech Republic & 1.8 & 65.5 \\
\hline Slovenia & 0.2 & 7.6 \\
\hline Poland & 2.9 & 15.0 \\
\hline Estonia & 5.4 & 4.3 \\
\hline
\end{tabular}

*2010

Source: Calculated from OECD data (2014). 
A more comprehensive approach to determining a post-socialist country's participation in a GVC consists of two stages. First, VA embodied in the country's domestic gross exports is decomposed. Second, foreign VA contained in its gross domestic exports and domestic value added to the exports of the country's trading partners are calculated (Koopman et al. 2010). Both indicators show whether
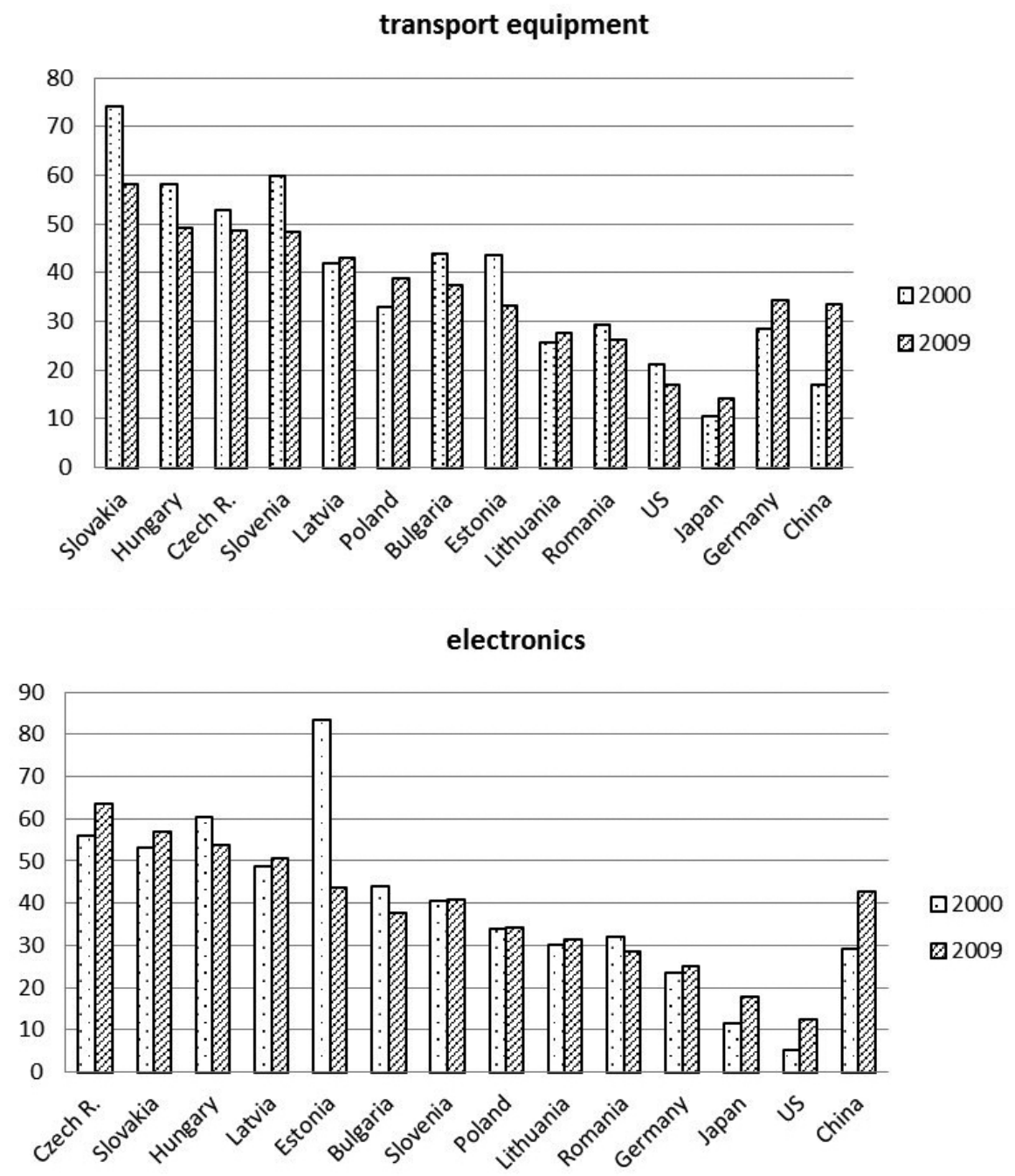

Graph 3. Proportions of foreign VA in the major recipient sectors of FDI in selected countries $(2000,2009, \%)$

Source: Based on TiVA OECD-WTO data (https://stats.oecd.org). 
Table 2. Stages in the production of transport equipment and electronics in selected countries $(2000,2009)$

\begin{tabular}{l|c|c|c|c|c|c|c|c}
\hline & \multicolumn{3}{|c|}{ Transport equipment } & \multicolumn{4}{c}{ Electronics } \\
\hline & $\begin{array}{c}\text { Index of the } \\
\text { number of } \\
\text { international } \\
\text { production stages }\end{array}$ & $\begin{array}{c}\text { Index of the } \\
\text { number of } \\
\text { domestic } \\
\text { production stages }\end{array}$ & $\begin{array}{c}\text { Index of the } \\
\text { number of } \\
\text { international } \\
\text { production stages }\end{array}$ & $\begin{array}{c}\text { Index of the } \\
\text { number of } \\
\text { domestic } \\
\text { production stages }\end{array}$ \\
\hline Slovakia & 2000 & 2009 & 2000 & 2009 & 2000 & 2009 & 2000 & 2009 \\
\hline Hungary & 1.8 & 1.6 & 1.2 & 1.4 & 1.3 & 1.4 & 1.4 & 1.5 \\
\hline Czech Republic & 1.4 & 1.3 & 1.4 & 1.3 & 1.2 & 1.5 & 1.3 & 1.4 \\
\hline Slovenia & 1.4 & 1.3 & 1.6 & 1.7 & 1.4 & 1.4 & 1.3 & 1.2 \\
\hline Latvia & 0.9 & 1 & 1.4 & 1.4 & 1 & 1 & 1.4 & 1.4 \\
\hline Poland & 0.8 & 1 & 1.6 & 1.5 & 1.7 & 1.1 & 1.1 & 1.3 \\
\hline Estonia & 0.8 & 0.8 & 1.4 & 1.5 & 1 & 1 & 1.3 & 1.3 \\
\hline Lithuania & 0.6 & 0.7 & 1.3 & 1.4 & 6 & 0.7 & 1.5 & 1.4 \\
\hline Romania & 0.7 & 0.6 & 1.6 & 1.5 & 0.5 & 0.6 & 1.6 & 1.7 \\
\hline Bulgaria & 0.9 & 0.8 & 1.5 & 1.9 & 1 & 0.9 & 1.4 & 1.7 \\
\hline Germany & 0.7 & 0.8 & 1.9 & 2 & 0.9 & 1 & 1.5 & 1.4 \\
\hline China & 0.4 & 0.5 & 2.8 & 3.1 & 0.3 & 0.9 & 1.7 & 1.6 \\
\hline USA & 0.5 & 0.5 & 2 & 1.8 & 0.3 & 0.4 & 2.1 & 2.1 \\
\hline Japan & 0.2 & 0.3 & 2.7 & 2.6 & 0.1 & 0.3 & 1.5 & 1.5 \\
\hline EU & 0.3 & 0.3 & 2.3 & 2.4 & 0.3 & 0.4 & 2 & 2 \\
\hline
\end{tabular}

Note: An index value approaching zero means that more components are made domestically. Moving away from zero the industry's dependence on foreign inputs increases.

Source: Based on TiVA OECD-WTO data (https://stats.oecd.org).

a country is climbing up or down a value chain. An increasing share of domestic VA in the exports of trading partners points to an upstream movement. An increasing share of foreign VA in a country's total exports is indicative of a downward movement.

For the purposes of this study, value added was decomposed for post-socialist countries as well as for the USA, Japan, and China, major links in GVCs. In comparing post-socialist countries to the world's largest economies, some degree of caution is necessary because the latter are relatively self-sufficient, so the proportion of foreign VA in their exports is much lower than in smaller countries with less developed internal markets. An analysis showed post-socialist countries differing significantly regarding the proportions of foreign VA contained in their exports. In 2009, proportions were highest and lowest in Slovakia and Romania, respectively $(<44 \%$ and $24 \%)$, but all post-socialist countries were below the EU average or had lower proportions than in the USA and Japan. For the sake of comparison, the proportions of domestic VA in their trading partners' exports fol- 
Table 3. Participation in GVCs $(2000,2009)$

\begin{tabular}{|c|c|c|c|c|c|c|c|c|c|}
\hline & $\begin{array}{l}\bar{a} \\
0 \\
0 \\
0 \\
0 \\
0 \\
0 \\
0 \\
0 \\
0 \\
0 \\
0 \\
0 \\
0 \\
0 \\
0\end{array}$ & & & & & & 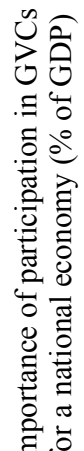 & & \\
\hline & 2000 & 2009 & 2000 & 2009 & 2000 & 2009 & 2009 & 2000 & 2009 \\
\hline $\begin{array}{l}\text { Czech } \\
\text { Republic }\end{array}$ & 39.18 & 39.39 & 22.2 & 23.0 & 61.38 & 62.39 & 25.80 & 0.57 & 0.58 \\
\hline Estonia & 50.06 & 33.22 & 18.7 & 21.3 & 68.76 & 54.52 & 24.85 & 0.37 & 0.64 \\
\hline Hungary & 46.19 & 39.91 & 17.2 & 18.7 & 63.39 & 58.61 & 25.40 & 0.37 & 0.47 \\
\hline Poland & 23.33 & 27.89 & 24.1 & 20.5 & 47.43 & 48.39 & 10.84 & 1.03 & 0.74 \\
\hline Slovakia & 48.26 & 44.35 & 21.2 & 17.9 & 69.46 & 62.25 & 30.77 & 0.44 & 0.4 \\
\hline Slovenia & 37.52 & 34.40 & 20.6 & 18.2 & 58.12 & 52.60 & 26.15 & 0.55 & 0.53 \\
\hline Bulgaria & 38.13 & 32.14 & 20.2 & 15.7 & 58.33 & 47.84 & 15.35 & 0.53 & 0.49 \\
\hline Latvia & 24.62 & 25.18 & 29.8 & 24.3 & 54.42 & 49.48 & 10.69 & 1.21 & 0.96 \\
\hline Lithuania & 32.56 & 36.05 & 17.7 & 14.1 & 50.26 & 50.15 & 26.00 & 0.54 & 0.39 \\
\hline Romania & 27.39 & 24.18 & 20.8 & 21.9 & 48.19 & 46.08 & 13.32 & 0.76 & 0.91 \\
\hline EU-27 & 12.63 & 13.62 & 18.0 & 17.8 & 30.63 & 31.42 & 4.29 & 1.43 & 1.31 \\
\hline China & 18.81 & 32.63 & 13.8 & 13.4 & 32.61 & 46.03 & 11.84 & 0.73 & 0.41 \\
\hline Germany & 24.40 & 26.64 & 24.4 & 22.8 & 48.80 & 49.44 & 17.34 & 1 & 0.86 \\
\hline USA & 8.88 & 11.29 & 31.1 & 28.5 & 39.98 & 39.79 & 4.02 & 3.5 & 2.52 \\
\hline Japan & 9.91 & 14.79 & 26.1 & 33.0 & 36.01 & 47.79 & 5.87 & 2.63 & 2.23 \\
\hline
\end{tabular}

Notes: Owing to a lack of more recent data, the last calculations were made for 2009.

Domestic VA in trading partners' exports was calculated using OECD-WTO indicators of participation.

The level of a country's participation in GVCs is established by adding domestic VA in the exports of its trading partners to foreign VA in its gross exports.

Source: Calculated on TiVA OECD-WTO data (https://stats.oecd.org).

lowed an upward trend. In 2009, they exceeded the EU average in most countries including Poland, but were still lower than in the USA or Japan (particularly high proportions were recorded in 2009 in Latvia and the Czech Republic, respectively $29.8 \%$ and $22.2 \%$ ). Post-socialist countries have high rates of GVC participation that is important for their economies (Table 3).

The above results point to the presence of two-way linkages in the vertical specialisations of post-socialist countries. On the one hand, they have a stronger 
presence in the downstream segment of GVCs compared with developed countries, meaning that they import foreign VA for the purposes of domestic exports. On the other hand, the foreign export share of VA originating in these countries is close to the EU average; this shows that they are gradually leaving behind countries outside the EU in the upstream segment of GVCs. In technologically advanced GVCs, post-socialist countries are ranked below developed countries.

An indicator of a country's relative position in GVCs shows greater strength of the downstream linkages. The higher its value, the higher the position a country has in the upstream segment with "one" as a threshold value dividing a GVC into downstream and upstream segments. The indicator showed post-socialist countries to be positioned in GVCs below the USA and Japan, and even below the EU average. In 2000, Latvia was the only country present in the upstream segment and Poland was on the threshold between segments, but the positions of both countries had worsened by 2009. The same trend affected most post-socialist countries except for the Czech Republic, Estonia, and Hungary, which had slightly improved their positions (Table 3).

Being the key trading partner of most post-socialist countries, Germany should be analysed in more detail. Its exports have a relatively high content of foreign VA, participation in GVCs is important for its economy, and the intermediate import share of domestic exports considerably exceeds levels recorded in other developed countries. Post-socialist countries and Germany strengthened their trade linkages in the 1990s. In Poland, Slovakia, the Czech Republic, and Hungary, trade volumes with Germany expanded particularly fast, the main reason being the special role of Germany as an intermediary facilitating access to intermediate goods (accounting for almost half of the trade between Germany and Poland). Vertical integration between post-socialist countries and Germany is particularly clear for more advanced products, primarily transport equipment. The strength of linkages between them is determined not only by different skills and costs of labour, but also by economic and cultural similarities, and geographical proximity (IMF 2013).

Post-socialist countries can also be considered in terms of their position in GVCs related to a particular industry. This part of the analysis focuses on industries that have achieved the highest level of internationalisation: transport equipment and electronics. As far as the production of transport equipment is concerned, five post-socialist countries (including Poland) were among the global leaders in the upstream segment. A special role in the later years of the sample was played by the automotive industry not only boosting the countries' exports, but also attracting major foreign investors. The automotive industry in the Baltic States, Slovenia, and Bulgaria has a shorter history, hence their lower positions in respective GVCs. Because electronic products are the traditional domain of the 
Diagram 1. The positions of post-socialist and selected other countries in GVCs in the transport equipment and electronics sectors (2009)

\begin{tabular}{|c|c|c|}
\hline & Transport equipment & Electronics \\
\hline 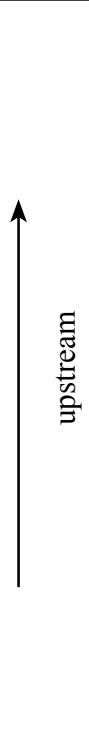 & $\begin{array}{l}\text { Japan (14) } \\
\text { USA (5.9) } \\
\text { Czech Republic (5.6) } \\
\text { Romania (3.9) } \\
\text { Hungary (3.8) } \\
\text { Germany (3.7) } \\
\text { S. Korea (3.4) } \\
\text { Slovakia (3.1) } \\
\text { Poland (2.8) } \\
\text { Italy (2.7) } \\
. . . . . . . .\end{array}$ & 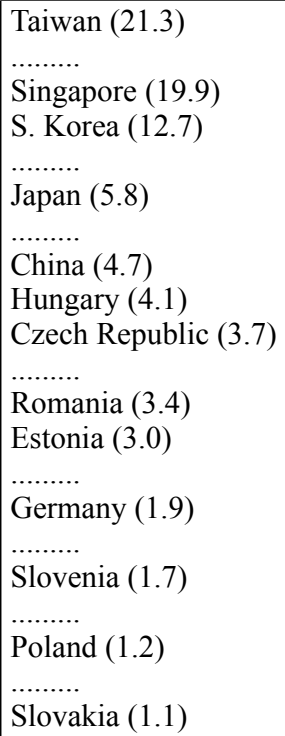 \\
\hline 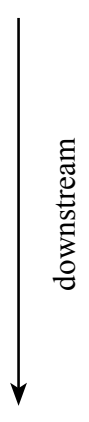 & $\begin{array}{l}\text { China }(0.9) \\
\ldots \ldots \ldots \ldots . \\
\text { Slovenia }(0.6) \\
\ldots \ldots \ldots . . . \\
\text { Estonia }(0.3) \\
\ldots \ldots \ldots . . \\
\text { Latvia }(0.2) \\
\ldots \ldots \ldots \ldots . \\
\text { Lithuania }(0.06) \\
\ldots \ldots \ldots \ldots . \\
\text { Bulgaria }(0.01) \\
\ldots \ldots \ldots . .\end{array}$ & $\begin{array}{l}\text { Bulgaria }(0.7) \\
\ldots \ldots \ldots . . . \\
\text { Latvia }(0.4) \\
\ldots \ldots \ldots . . \\
\text { Argentina }(0.3) \\
\text {......... }\end{array}$ \\
\hline
\end{tabular}

Note: The diagram contains countries for which OECD-WTO statistics are available. GVCs were constructed using relative positions in particular sectors of industry.

Source: Calculated on TiVA OECD-WTO data (https://stats.oecd.org).

"Asian tigers", post-socialist countries occupy positions lower down the electronics supply chains. The highest positions were attained by Hungary and the Czech Republic; Poland was in the upstream segment too, but far behind the value chain leaders (Diagram 1). 


\section{CONCLUSIONS}

The European post-socialist countries have significantly improved their economic systems in the last two decades and redirected their trade from the former Council for Mutual Economic Assistance members to EU markets. In almost all of them, trade patterns increasingly resemble those in the EU.

Post-socialist countries' integration with the EU and the adoption of its trading rules has brought measurable benefits such as a fast expanding volume of trade, particularly in the first years after accession. However, the recent international economic crisis has not only partly reduced trading profits, but also showed the weak points of European integration, such as a lower volume of trade with nonEU countries in Asia and Africa.

Strengthening integration gave post-socialist markets an opportunity to join regional value chains, ${ }^{7}$ while their trade and capital linkages with the EU-15 grew stronger too, particularly in high technology sectors. Their decision to join the EU can be rightly perceived as a major move intended to spur their development and bring them closer to the EU-15, but it also made them more sensitive to industrial and demand shocks coming from the euro zone. Although the recent global crisis quickly exposed the weaknesses of integration with the EU, its present model is not likely to change, particularly regarding participation in GVCs. It is quite possible, however, that integration in foreign trade will not be at the same level as today.

The analysis of post-socialist countries' positions in global value chains leads to the following conclusions. Firstly, countries have different GVC participation rates, and those of them that closely cooperate with Western European countries, especially with Germany, are more integrated with GVCs. Secondly, a considerable proportion of post-socialist exports go through Western European GVCs. Thirdly, most exporters in Central and Eastern Europe have lower positions in value chains.

The limitations of this study are due to the limited availability of statistical data, the most recent of which were generated in 2009. Because the GVCs were analysed using data ending in 2009, after which negative trends appeared in trade with most EU countries, including CEE, future studies into the role of post-socialist countries in GVCs should be extended beyond 2009. It is quite possible that the new data will rank the countries differently.

7 One indication that the process is taking place is the similar rates of economic growth between the eurozone and post-socialist countries. 


\section{REFERENCES}

Akbar, Y. - Ferencikova, S. (2007): Industrial Clustering and Global Value Chains in Central and Eastern Europe: Role of Multinational Enterprises in Industrial Upgrading. Prague Economic Papers, 16(3): 237-251.

Altomonte, C. - di Mauro, F. - Ottaviano, G. - Rungi, A. - Vicard, V. (2012): Global Value Chains during the Great Trade Collapse: A Bullwhip Effect? Working Paper Series, 1412, European Central Bank.

Amador, J. - Cappariello, R. - Stehrer, R. (2013): Global Value Chains: A View from the Euro Area. CompNet Conference, Washington, D.C. pp. 16-17.

Ambroziak, Ł. (2013): Wplyw bezpośrednich inwestycjizagranicznych na handel wewnątrzgatęziowy państw Grupy Wyszehradzkiej (The impact of foreign direct investment on the intra-industry trade of the Visegrad Group). Warszawa: Monografie IBRKK.

Ananicz, S. - Sadowski, R. (2012): Central Europe Facing Eastern Europe: Symphony or Cacophony? In: Regional and International Relations of Central Europe. New York: Palgrave Macmillan, pp. 287-288.

Backer, K. D. - Miroudot, S. (2013): Mapping Global Value Chains, OECD, Trade Policy Papers, No. 159.

Baszyński, A. (2013): Transformacja sektora bankowego w krajach Europy Środkowej, Wschodniej i Południowo-Wschodniej (The transformation of the banking sector in Central, Eastern and South-Eastern Europe). Wiadomości Statystyczne, 7, 80-98.

Behar, A. - Freund, C. (2011): Factory Europe? Brainier but not Brawnier. FREIT Working Paper 312, Forum for Research in Empirical International Trade (FREIT).

Błasiak, W. (2013): Pomiędzy centrum a peryferiami na progu XXI wieku (Between the center and the periphery on the threshold of the $21^{\text {st }}$ century). Katowice: Śląsk Wydawnictwo Naukowe.

Cieślik, E. (2012): Efekt smoka. Skutki ekspansji gospodarczej Chin po 1978 roku (The dragon effect. The results of China's economic expansion since 1978). Warszawa: CeDeWu.

Cieślik, E. (2014a): Post-Communist European Countries in Global Value Chains. Ekonomika, 93(3): 25-38.

Cieślik, E. (2014b): Prospects for Trade Growth between Poland and China, Studia Ekonomiczne, PAN, 4: 495-515.

Cieślik, E. (2015): Rozwój gospodarczy Chin od roku 1978 do kryzysu globalnego (China's economic development from 1978 to the global crisis). Warszawa: Wydawnictwo Key Text.

De Simone, G. (2008): Trade in Parts and Components and the Industrial Geography of Central and Eastern European Countries. Review of World Economics, 144(3): 428-457.

Dicken, P. - Kelly, P. - Olds, K. (2011): Chains and Networks, Territories and Scales: Towards a Relational Framework for Analysing the Global Economy. Global Networks, April, pp. 89-112.

Dobrinsky, R. (1995): Economic Transformation and the Changing Patterns of European East - West Trade, Transforming Economies and European Integration. Edward Elgar, UK, pp. 8690.

Feenstra, R. (1998): Integration of Trade and Disintegration of Production in the Global Economy. Journal of Economic Perspectives, 12(4): 31-50.

Feenstra, R. - Hanson, G. (1999): The Impact of Outsourcing and High-Technology Capital on Wages: Estimates for the United States, 1979-1990. The Quarterly Journal of Economics, 114(3): 907-940.

Ferreira-Lopes, A. - Neves Sequeira, T. (2014): The Dynamics of the Trade Balance and the Terms of Trade in Central and Eastern European Countries. Acta Oeconomica, 64(1): 51-71. 
Fortwengel, J. (2011): Upgrading through Integration? The Case of the Central Eastern European Automotive Industry. Transcience Journal, 2(1): 1-25.

Foster, N. - Stehrer, R. - Timmer, M. (2013): International Fragmentation of Production, Trade and Growth: Impacts and Prospects for EU Member States. European Economy - Economic Papers, No. 484, Directorate General Economic and Financial Affairs (DG ECFIN), European Commission.

Hummels, D. - Ishii, J. - Yi, K. (2001): The Nature and Growth of Vertical Specialization in World Trade. Journal of International Economics, 54: 75-96.

IMF (2011): East - West Economic and Financial Linkages in Europe. Europe Regional Economic Outlook. Washington, D.C.

IMF (2013): German - Central European Supply Chain - Cluster Report. Washington, D.C.

Iossifov, P. (2014): Cross-Border Production Chains and Business Cycle Co-Movement between Central and Eastern European Countries and Euro Area Member States. European Central Bank Working Paper Series, Issue 1628. Frankfurt am Mein.

Jacoby, W. (2010): Managing Globalization by Managing Central and Eastern Europe: The EU's Backyard as Threat and Opportunity. Journal of European Public Policy, 17(3): 416-432.

Jürgens, U. - Krzywdzinski, M. (2009): Changing East-West Division of Labour in the European Automotive Industry. European Urban and Regional Studies, 16(1): 27-42.

Kaminski, B. - Ng, F. (2005): Production Disintegration and Integration of Central Europe into Global Markets. International Review of Economics and Finance, 14: 377-390.

Koopman, R. - Powers, W. - Wang, Z. - Wei, S.-J. (2010): Give Credit Where Credit Is Due: Tracing Value Added in Global Production Chains. NBER Working paper, 16426.

Kornai, J. (1994): Transformational Recession: The Main Causes. Journal of Comparative Economics, 19(1): 39-63.

Labrianidis, L. - Domanski, B. - Kalantaridis, C. - Kilvits, K. - Roukova, P. (2008): The Moving Frontier: The Changing Geography of Production in Labour Industries. Specific Targeted Research Project Final Report. Brussels.

Marin, D. (2006): A New International Division of Labor in Europe: Outsourcing and off-Shoring to Eastern Europe. Journal of the European Economic Association, 4(2-3): 612-622.

Maćkowiak, H. (2011): The Goods Structure of Trade between Polish Regions and the European Union. Bulletin of Geography. Socio-economic Series, 16: 57-74.

McKinsey Global Institute (2013): A New Dawn: Reigniting Growth in Central and Eastern Europe.

Mihályi, P. (2001): The Evolution of Hungary's Approach to FDI in post-Communist Privatization. Transnational Corporations, 10(3): 61-74.

NBP (2014): Sytuacja gospodarcza w krajach Europy Środkowej i Wschodniej (The economic situation in the countries of Central and Eastern Europe), Warsaw: National Bank of Poland.

Pavlinek, P. (2005): Transformation of the Central and East European Car Passenger Industry: Selective Peripheral Integration through Foreign Direct Investment. In: Turnock, D. (ed.): Foreign Direct Investment and Regional Development in East Central Europe and the Former Soviet Union. Burlington: Ashgate, pp. 71-102.

Rynarzewski, T. (2013): Refleksje o dylematach wpływu handlu zagranicznego na rozwój gospodarczy krajów słabo zaawansowanych ekonomicznie (Some thoughts on the dilemmas regarding the influence of foreign trade on the economic development of less economically advanced countries). Studia Oeconomica Posnaniensia, pp. 69-90.

Sass, M. - Szalavetz, A. (2013): Crisis and Upgrading: The Case of the Hungarian Automotive and Electronics Sectors. Europe-Asia Studies, 65(3): 489-507. 
Simkova, O. (2013): Central and Eastern Europe: Moving up the Value Chain Resilience. PricewaterhouseCoopers, pp. 18-25.

Stehrer, R. - Borowiecki, M. - Dachs, B. - Hanzl-Weiss, D. - Kinkel, S. - Pöschl, J. - Sass, M. - Schmall, T. C. - Szalavetz, A. ( 2012): Global Value Chains and the EU Industry. Wiiw Research Reports 383. The Vienna Institute for International Economic Studies (wiiw). October.

Stehrer, R. - Foster, N. - deVries, G. (2012): Value Added and Factors in Trade. A Comprehensive Approach. World Input-Output Database Working Paper, No. 7.

Środa-Murawska, S. (2011): Selected Aspects of Changes in Trade Network in the Period 19952003 from the Perspective of Polish Small Towns. Bulletin of Geography. Socio-Economic Series, 8: 151-161.

Timmer, M. P. - Los, B. - Stehrer, R. - de Vries, G. J. (2012): Fragmentation, Incomes and Jobs: An Analysis of European Competitiveness. Economic Policy, 28(76): 613-661.

The World Bank (2014a): World Development Indicators.

The World Bank (2014b): World Integrated Trade Solution.

United Nations (2014): UN Comtrade.

World Economic Forum (2013): The Global Competitiveness. Geneva. 